\title{
OBJEK DALAM METAFORA DAN AKAL BUDI MELAYU
}

\section{(Objects in Malay Metaphors and the Malay Mind)}

\author{
Nor Hashimah Jalaluddin \\ shima@ukm.edu.my \\ Program Linguistik \\ Pusat Kajian Bahasa dan Linguistik \\ Universiti Kebangsaan Malaysia
}

Terbit dalam talian (published online): 7 Julai 2020

Sila rujuk: Nor Hashimah Jalaluddin. (2020). Objek dalam Metafora dan Akal Budi Melayu. Melayu: Jurnal Antarabangsa Dunia Melayu, 13(2), 199-222.

\begin{abstract}
Abstrak
Simpulan bahasa, peribahasa, simile dan pantun dimasukkan di bawah kategori metafora Melayu. Menariknya, metafora ini bukan semata-mata harfiah sifatnya, bahkan sarat dengan falsafah yang dapat membawa kita memahami pemikiran Melayu. Jelasnya, metafora ini terbentuk dengan adanya objek khusus yang mempunyai pertalian yang rapat dengan makna, maka adalah berbaloi untuk dilihat hubungan ini dengan makna yang hendak disampaikan. Kajian ini memfokuskan pada data simpulan bahasa "mata" dan "kuku". Ulam-ulaman dipilih bagi mewakili pantun. Semua data ini diambil daripada www.malaycivilization.com. Data telah dianalisis menggunakan semantik inkuisitif dan diupayakan untuk mencungkil peranan kognitif, falsafah dan budaya bagi menghuraikan mengapa sesuatu objek dipilih dalam metafora tersebut. Terdapat tiga langkah yang diambil sebelum makna sebenar dicapai, iaitu, makna harfiah, kognitif dan inkuisitif. Dapatan kajian membuktikan bahawa objek "mata", "kuku" dan "ulam-ulaman" membawa makna yang sangat bertepatan dengan maksud yang hendak disampaikan. Objek "mata", berkaitan dengan isyarat perasaan, objek "kuku" berkaitan dengan keakraban dan "ulam-ulaman" dengan kasih sayang dapat dibuktikan melalui data yang dipilih. Huraian ini seterusnya digabungkan dengan ilmu lain seperti perubatan bagi simpulan bahasa dan khasiat pemakanan bagi pantun. Jelasnya, kajian bersifat multidisiplin ini mampu menghuraikan metafora Melayu secara saintifik dan meyakinkan.
\end{abstract}

Kata kunci: Objek, metafora, pantun, akal budi Melayu, falsafah, budaya

(C) Dewan Bahasa dan Pustaka. 2020. This work is licensed under the term of the Creative Commons Attribution (CC BY) (http://creative commons.org/licenses/by/4.0/)

ISSN 1675-6460 e-ISSN 2682-8049 


\section{Abstract}

Idioms, proverbs, similes and pantun all fall under the category of "metaphor" in Malay. Interestingly, the metaphors are not superficial; instead, they are permeated with philosophy, which in turn convey Malay thought. Clearly, these metaphors are composed using specific objects that have a close connection with meaning. Therefore, it is worthwhile to examine this connection and the meaning that is meant to be conveyed. This study focuses on data concerning idioms about mata[eyes] and kuku [fingernails]. References to ulam-ulaman (herbal plants eaten raw) were chosen for analysis of pantun. All of the data was taken from www.malaycivilization. com. The data analysis was performed using inquisitive semantics in an effort to uncover cognitive philosophical and cultural roles to explain why a particular object is selected for a particular metaphor. The actual meaning is revealed through three steps: literal, cognitive and inquisitive. The findings of this study show that the objects mata and kuku, as well as herbal plants, are aptly used to suggest the meaning that they are to convey. Mata signals feelings, kuku concerns closeness and herbal plants are associated with love, as proven by the data selected. The discussionthen extends to other fields, medicine and nutrition, in reference to proverbs and pantun. Clearly, this kind of multidisciplinary study is able to discuss Malay metaphors scientifically and convincingly.

Keywords: object, metaphor, pantun, Malay mind, philosophy, culture

\section{PENGENALAN}

Residen British di Tanah Melayu seperti Maxwell (1878), Winstedt (1950) dan Wilkinson dan Winstedt (1957) mengagumi bahasa dan persuratan Melayu. Mereka menghasilkan buku tatabahasa dan kamus Melayu. Maxwell menyarankan untuk memahami masyarakat Melayu, maka peribahasa dan pantun pasti menjadi rujukan utama. Sehingga kini sarjana Barat seperti Goddard (1999), Black $(2000,2002)$ meneliti peribahasa Melayu dan dikaitkan dengan pemikiran masyarakat Melayu. Peribahasa boleh dimasukkan di bawah metafora. Metafora secara umumnya ungkapan yang mempunyai rantaian perkataan tetapi mempunyai makna yang berbeza dengan apa-apa yang terungkap secara harfiah (Hassan, 2003). Metafora mengandungi makna abstrak yang kerap digunakan dalam kehidupan kita. Metafora bukan bunga-bunga bahasa atau bahasa yang menyeleweng daripada bahasa harfiah. Menurut Hassan (2003) lagi, metafora mempunyai fungsi kognitif, iaitu untuk membentuk fikiran dan makna yang luar biasa, atau makna yang bersifat abstrak atau konseptual. Hari ini kita ada metafora tradisional dan metafora linguistik. Metafora 
tradisional merujuk kiasan yang terkandung dalam simpulan bahasa, peribahasa, perumpamaan, perbidalan malah pantun juga kerana semua ungkapan ini mempunyai makna tersirat dan makna abstrak yang memerlukan interpretasi semantik yang mendalam. Metafora linguistik pula merujuk ungkapan hari ini yang mengandungi makna implisit dengan fungsi kognitif serta makna konseptual. Metafora linguistik bukanlah tinggalan pusaka tetapi ungkapan yang boleh dihasilkan oleh sesiapa sahaja dengan syarat bersifat tersirat dan masih mempunyai ciri konseptual. Hal ini ditegaskan oleh Lakoff dan Johnson (1980, p. 1), "our ordinary conceptual system, in terms of which we think and act, is fundamentally metaphorical in nature".

Masyarakat Melayu sangat erat dengan alam sekeliling dan lingkungan kehidupan mereka. Bukan setakat alam sekeliling mereka, malahan deria, anggota tubuh badan dan hati telah dijadikan analogi metafora yang berguna. Menurut Asmah (1986) manusia membentuk persepsi berdasarkan apa-apa yang ada di sekelilingnya. Daripada persepsi timbul konseptualisasi yang membolehkan manusia menggunakan lambang bahasa untuk merakamkan fikiran dan pengalamannya. Maka dengan itu, lain masyarakat lain bahasanya, dan lain persepsinya. Azhar (1993) menegaskan bahawa bahasa Melayu bersifat peka konteks. Bukan setakat metaforanya malah tatabahasanya juga. Jika diteliti, penggunaan metafora misalnya menggambarkan keintelektualan masyarakat penuturnya. Hassan $(2003,2016)$ menggunakan istilah akal budi atau kehalusan akal yang bermaksud lebih tinggi daripada intelektual apabila menghuraikan metafora Melayu. Hassan telah menggunakan data peribahasa, lipur lara, hikayat, dan puisi bagi menjelaskan metafora Melayu yang hebat dan lantas mengaitkan dengan akal budi penutur Melayu.

Nor Hashimah $(2014,2018)$ merumuskan pendapat sarjana di atas dengan memperkemas definisi akal budi. Akal budi merupakan cerminan kebijaksanaan mengungkap dan menguraikan makna. Makna dilihat dengan "mata hati", diberikan tafsiran mendalam dan terperinci sehingga dapat mencungkil makna yang sebenar yang hendak disampaikan. Pemilihan leksis dan objek, terutamanya yang menyangkut dengan alam, anggota badan dan deria semuanya mempunyai justifikasi yang kukuh. Tambahan lagi, dengan makna yang terhasil amat berpadanan dengan susuk bahasa yang hendak disampaikan. Jika Hassan $(2003,2016)$ melihat akal budi Melayu melalui metafora, Nor Hashimah (2014) juga menghuraikan akal budi pada tatabahasa bahasa Melayu seperti imbuhan, penggandaan, kata bilangan kardinal di samping metafora Melayu.

Artikel ini akan meneruskan pengkajian mengenai metafora tradisional Melayu bagi membuktikan bahawa penutur Melayu memang bijak dan ini terserlah melalui akal budinya. Meskipun sarjana hari ini (Rogayah, 2011; Imran, 2011) telah beralih 
kepada metafora linguistik tetapi artikel ini akan meneruskan dengan metafora tradisional kerana olahan metafora ini lebih mencabar dan dapat mencerminkan akal budi Melayu. Semua objek dan lingkungan yang digunakan dalam membentuk metafora Melayu akan dikupas. Analisis metafora ini menggunakan semantik inkuisitif, iaitu pendekatan yang menggabungkan data, teori, kognitif, falsafah dan budaya penuturnya sehingga mampu mencungkil akal budi masyarakat Melayu khususnya. Nor Hashimah (2018) ingin membuktikan bahawa selain halus penciptaan metafora Melayu, wujudnya ilmu yang bersifat multidisiplin dalam mencorakkan metafora Melayu ini. Tumpuan akan diberikan kepada metafora "mata" dan "kuku". Sebagai peneguhan, data pantun ulam-ulaman dikupas bersama-sama dengannya.

\section{KERELEVANAN KAJIAN METAFORA MELAYU}

Kajian tentang metafora tradisional seperti simpulan bahasa, peribahasa, perumpamaan dan pantun masih relevan sehingga ke hari ini. Meskipun ada yang berpendapat metafora ini merupakan tinggalan nenek moyang yang tidak difahami dan tidak lagi dipakai oleh generasi muda hari ini, namun tanggapan itu boleh disangkal. Sehingga ke hari ini, peribahasa masih dikaji oleh sarjana tempatan mahupun Barat. Goddard (1999) mengupas mengenai "bagaimana ketam mengajar anak berjalan" dan dikaitkan dengan sistem politik Malaysia. Black $(2000,2002)$ mengupas metafora tradisional mata, kaki, lidah bercabang dan membandingkannya dengan metafora bahasa Inggeris, dan ternyata kedua-dua bahasa ini mempunyai perbezaan kerana lingkungan persekitaran yang berbeza.

Kajian metafora dalam negara juga banyak dilakukan. Kajian tentang simpulan bahasa, peribahasa, perumpamaan dan pantun masih mendapat perhatian. Malah kini ada yang membuat perbandingan antara budaya contohnya Imran Ho (2011) yang mengkaji peribahasa "anjing". Imran mendapati persepsi manusia berbeza mengikut budaya. Dari segi kognitifnya, anjing diberikan tanggapan negatif dalam masyarakat Melayu sementara anjing dianggap kawan yang setia dalam masyarakat Barat. Keadaan ini pastinya ada kaitan dengan lingkungan persekitaran. Jamuna (2015) yang mengkaji peribahasa Tamil berobjekkan "gajah" juga memberikan perspektif positif dan negatif pada objek gajah dalam masyarakat Hindu. Rogayah (2011) pula mengkaji mengenai deria, manakala Zaitul Azma dan Ahmad (2011) mengenai nilai murni peribahasa berdasarkan objek alam. Sarjana di atas semua berpegang kepada objek dan mentafsirkan makna sehingga melahirkan nilai-nilai yang menjadi pegangan masyarakat. Kesemua sarjana ini melihat peranan kognitif untuk memahami peribahasa. 
Nor Hashimah (2014) mendakwa bahawa kajian metafora setakat peringkat kognitif tidak berupaya memberikan makna sebenar yang hendak disampaikan. Pemahaman pada metafora menuntut pemahaman lateral. Banyak tafsiran yang boleh diberikan, interpretasinya boleh bercambah, ditambah pula metafora bersifat implisit lagi abstrak. Metafora Melayu sangat bergantung pada persekitaran. Dengan itu, kita perlu lebih daripada tahap kognitif untuk memahami metafora Melayu. Nor Hashimah $(2014,2018)$ menggagaskan semantik inkuisitif, iaitu setahap lagi melangkaui kognitif penutur.

Untuk mendapatkan pentafsiran yang sempurna, terdapat beberapa proses yang perlu dilakukan. Bermula daripada makna harfiah atau pengkaji memanggilnya sebagai semantik skrip, kita melangkah ke interpretasi kognitif. Daripada konsep kognitif ini, maka dibuat pemetaan antara makna abstrak dan konkrit. Pengkaji menamakan makna kognitif ini sebagai semantik resonans. Untuk mencungkil makna yang abstrak itu, harus dicari domain sumbernya dahulu. Bagaimana alam realiti yang rapat dengan kehidupan manusia dimanfaatkan bagi memahami makna yang abstrak? Pengkaji memulakan dengan contoh "bagai mentimun dengan durian". Makna metafora ini mudah untuk difahami. Penutur harus bergerak dari benda yang konkrit daripada domain sumber. Ciri durian yang kuat dari segi bau, fizikal, kulit dan rasa mampu menghancurkan timun yang dikatakan mempunyai sifat lemah. Lemah merujuk pada sifatnya yang mudah pecah, berair dan mudah rosak. Berasaskan maklumat domain sumber maka makna dalam domain sasaran dapat difahami dan dapat dilakukan analogi. Domain sasaran yang dilabelkan sebagai A pastinya akan bergantung pada domain sumber yang dilabelkan B. Hal ini pernah dibincangkan dalam Hassan (2016) cuma huraiannya dipermudah seperti dalam Rajah 1. Rajah 1 di bawah dapat menjelaskan tentang proses pemetaan pada peringkat kognitif ini.

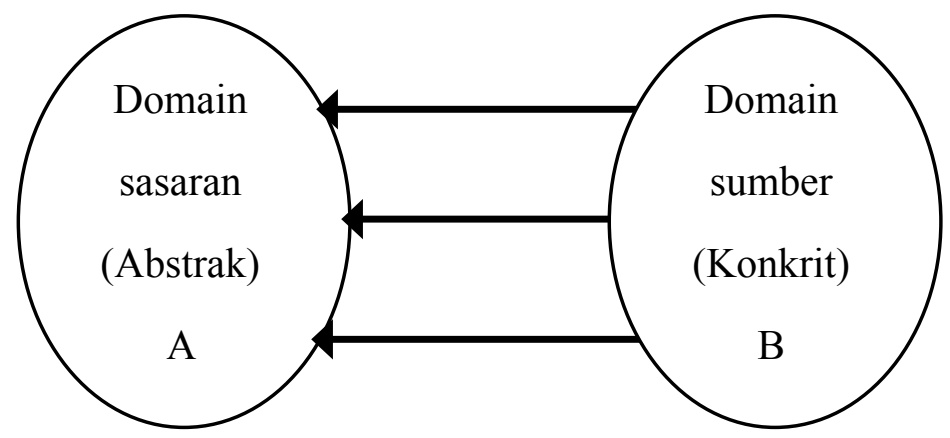

Rajah 1 Pemetaan domain. 
Jadi formula memahami metafora yang konkrit ialah "A ialah B" bukan sebaliknya (Hassan, 2016). Namun begitu, hubungan sehala (unidirectional) ini harus melalui satu proses yang dinamakan proses ruang mental (mental space). Di sinilah maklumat bukan linguistik diperkaya bagi memastikan tafsiran kepada bentuk abstrak itu mudah difahami. Dalam teori Relevans, boleh digunakan maklumat konteks dan kesan kognitif untuk memenuhkan ruang mental ini bagi memastikan kos memproses maklumat menjadi rendah dan metafora akan mudah difahami. Dalam istilah semantik kognitif, ruang mental ini boleh diisi dengan pengalaman jasadiah (experiential embodiment). Perhatikan bagi ruang mental, pendengar boleh memasukkan elemen bukan linguistik untuk membantu mendapatkan makna yang konkrit. Jika pada peringkat semantik kognitif hanya menyebut pengalaman jasadiah atau konteks tetapi penulis berpendapat pengalaman jasadiah atau konteks dan kesan kognitif dapat diperincikan lagi dengan memasukkan falsafah dan budaya. Bagi memudahkan cara pemetaan domain, Rajah 2 di bawah boleh dimanfaatkan.

\begin{tabular}{|c|c|c|}
\hline $\begin{array}{l}\text { makna abstrak } \\
\text { Orang yang lemah } \\
\text { melawan orang yang } \\
\text { kuat; perlawanan yang } \\
\text { tidak sebanding. } \\
\text { Ciri abstrak: } \\
\text { lemah lawan kuat }\end{array}$ & $\begin{array}{l}\text { ruang mental } \\
\text { di sini proses kognitif } \\
\text { terlibat demi } \\
\text { melakukan pemetaan } \\
\text { makna konkrit dengan } \\
\text { makna abstrak. Disini } \\
\text { maklumat konteks, } \\
\text { kesan kognitif atau } \\
\text { pengalaman jasadiah } \\
\text { boleh membantu } \\
\text { menjelaskan hal yang } \\
\text { abstrak. }\end{array}$ & $\begin{array}{l}\text { makna konkrit } \\
\text { Contoh peribahasa: } \\
\text { seperti mentimun } \\
\text { dengan durian. } \\
\text { Cirikonkrit: } \\
\text { lemah dari segi: mudah } \\
\text { pecah, berair, mudah } \\
\text { rosak. } \\
\text { kuat dari segi: bau, } \\
\text { rasa, tajam, fizikal kulit }\end{array}$ \\
\hline
\end{tabular}

Rajah 2 Proses yang berlaku dalam minda bagi mendapatkan makna metafora.

Di manakah semantik inkuisitif beroperasi? Lanjutan daripada Rajah 2 di atas, dihuraikan bagaimana semantik inkuisitif ini dapat dimanfaatkan. Nor Hashimah $(2014,2018)$ menghuraikan bahawa terdapat tiga tahap semantik di Malaysia. Kajian metafora tradisional yang terhenti setakat makna padanan dan tiada huraian lanjut dilabelkan sebagai semantik skrip telah dijalankan oleh sarjana seperti Abdul Samad (1989) dan Abdullah Hussain (2003). Mereka menyenaraikan makna metafora yang diberikan. Kemudian kajian metafora bergerak setingkat lagi, iaitu pada peringkat kognitif seperti yang diterangkan di atas (lihat Rajah 1 \& 2). Pengkaji menamakan peringkat kognitif ini sebagai semantik resonans. Memandangkan metafora Melayu 
ini mempunyai unsur akal budi (keintelektualan yang tinggi), huraian kognitif masih tidak memadai. Dengan itu, Nor Hashimah (2014) mencadangkan dimasukkan maklumat falsafah dan budaya bagi mencungkil akal budi di sebalik metafora ini. Di sinilah tahap tiga atau semantik inkuisitif memainkan peranannya sehingga tercapai akal budi penutur Melayu. Rajah 3 menjelaskan lagi letaknya semantik inkuisitif.

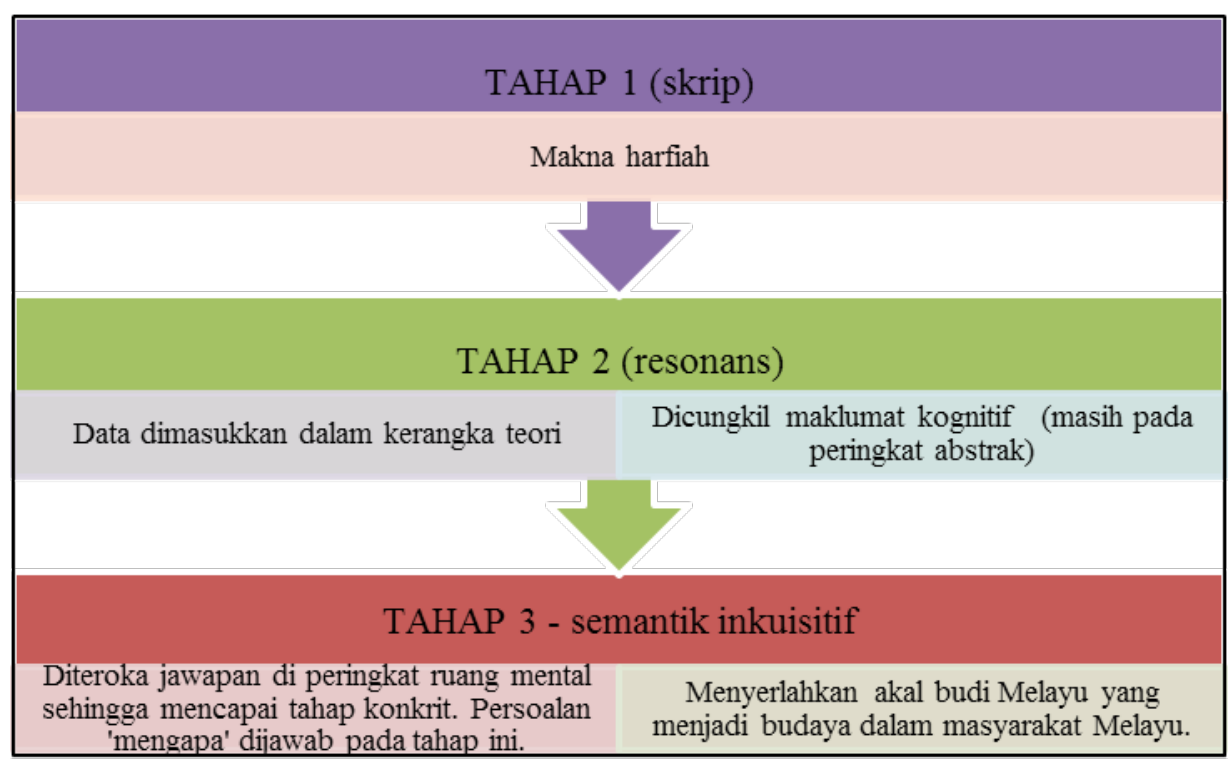

Rajah 3 Urutan tahap semantik (Jalaluddin, 2017).

Dalam Rajah 3, peringkat ruang mental berada pada tahap 3 yang diperkemas dengan menjawab persoalan "mengapa" dan "kenapa". Mengapa dan kenapa objek dan makna dipadankan akan terjawab pada peringkat semantik inkuisitif. Bagi menjelaskan bagaimana semantik inkuisitif dapat menghuraikan metafora tradisional ini dengan baik, maka data daripada simpulan bahasa "mata" dan "kuku" akan dihuraikan. Kemudian analisis akan dikukuhkan lagi dengan tafsiran pantun. Pada peringkat ini akan ditunjukkan cara semantik skrip, kognitif dan inkuisitif beroperasi sehingga tercungkilnya akal budi Melayu.

\section{MENEROKA AKAL BUDI MELAYU}

Terdapat dua contoh kukuh daripada simpulan bahasa dan empat contoh daripada pantun yang boleh membuktikan rapatnya hubungan metafora dengan alam sekitar 
dan lingkungan kehidupan manusia. Malah lebih menarik lagi adanya rangkuman kupasan multidisiplin bagi kita memahami mengapa objek tersebut dipilih dalam metafora yang dikaji.

\section{Data Simpulan Bahasa}

Dua contoh yang menarik telah dipilih, iaitu "mata" dan "kuku" yang merupakan sebahagian daripada tubuh badan kita. Orang Melayu dahulu mengambil lingkungan terdekat bagi membentuk analogi dan pada masa yang sama membantu pendengar memahami mesej yang hendak disampaikan menemui sasarannya. Oleh sebab itu, metafora tradisional boleh bertahan sehingga ke hari ini. Pantun pula mengambil banyak objek alam untuk dijadikan pembayang dan sekali gus memberikan klu kepada makna yang hendak disampaikan. Kesemua ini mengandungi elemen kognitif yang penting dalam metafora tradisional Melayu ini.

\section{(1) Simpulan Bahasa "MATA"}

Daripada Jadual 1, lajur ketiga dikategorikan sebagai makna harfiah yang dimasukkan dalam semantik skrip. Hanya makna padanan yang diperoleh. Langkah pertama ini adalah untuk memahami makna. Sementara kategori makna dalam lajur keempat boleh dimasukkan dalam kategori semantik resonans dan di sini makna kognitif turut diberi. Langkah ini merupakan langkah kedua. Daripada makna yang telah tercatat, didapati simpulan bahasa berputih mata dan mata merah dari segi kognitifnya berkaitan dengan perasaan, iaitu perasaan kecewa dan sedih. Oleh itu, kategori makna yang dapat dibentuk ialah "mata" dapat dikaitkan dengan isyarat perasaan. Simpulan bahasa mengaburi mata dan rambang mata pula berkaitan dengan penipuan dan pemilihan. Sekiranya sesuatu perkara itu tidak dinilai dengan baik, maka seseorang akan mudah tertipu dan tersalah membuat pilihan. Oleh itu, dikaitkan makna "mata" dalam simpulan ini sebagai entiti yang tidak jelas yang boleh mendatangkan keburukan jika tidak diteliti dengan betul. Daripada definisi yang tercatat bagi simpulan bahasa mata pisau, mata gergaji dan mata kail, kesemuanya boleh dikaitkan dengan sesuatu yang tajam. Oleh itu, kategori makna yang dapat dibentuk tentang mata dalam simpulan bahasa ini ialah ketajaman objek. Simpulan bahasa mata hati juga merujuk "mata" itu sebagai ketajaman. Namun begitu, kategori makna yang dibentuk ialah ketajaman daya taakul. Mata di sini berperanan untuk memperhalusi dan mencermati sesuatu perkara (Noorfaiz, 2016). Bagaimana tafsiran di atas dibuat? Tafsiran terbaik untuk menyingkap kognitifnya adalah dengan menggunakan teori Relevans (Sperber D. \& Wilson D. 1995.). Teori ini mengaitkan 
Jadual 1 Pencerakinan metafora "MATA" (Pakharadzi, 2016).

\begin{tabular}{|c|c|c|c|}
\hline Sifat mata & $\begin{array}{c}\text { Simpulan } \\
\text { Bahasa }\end{array}$ & Makna & Kategori Makna \\
\hline \multirow{2}{*}{ Warna Mata } & berputih mata & $\begin{array}{l}\text { Sangat kecewa; } \\
\text { menanggung malu }\end{array}$ & \multirow{2}{*}{ Isyarat perasaan } \\
\hline & mata merah & Bersedih & \\
\hline \multirow{2}{*}{$\begin{array}{l}\text { Keadaan mata } \\
\text { yang tidak sihat }\end{array}$} & $\begin{array}{l}\text { mengaburi } \\
\text { mata }\end{array}$ & $\begin{array}{l}\text { Tipu dengan cara } \\
\text { mengeliru }\end{array}$ & \multirow{2}{*}{$\begin{array}{l}\text { Entiti yang tidak } \\
\text { jelas }\end{array}$} \\
\hline & rambang mata & $\begin{array}{l}\text { Keliru untuk } \\
\text { membuat pilihan }\end{array}$ & \\
\hline \multirow{4}{*}{$\begin{array}{l}\text { Berkaitan dengan } \\
\text { ketajaman } \\
\text { penglihatan }\end{array}$} & mata pisau & $\begin{array}{l}\text { Bahagian tajam } \\
\text { pada pisau }\end{array}$ & \multirow{3}{*}{$\begin{array}{l}\text { Ketajaman } \\
\text { Objek }\end{array}$} \\
\hline & mata gergaji & Gerigi gergaji & \\
\hline & mata kail & $\begin{array}{l}\text { Bahagian yang } \\
\text { tajam pada kail }\end{array}$ & \\
\hline & mata hati & $\begin{array}{l}\text { Fikiran; perasaan } \\
\text { dalam hati }\end{array}$ & $\begin{array}{l}\text { Ketajaman } \\
\text { daya taakul }\end{array}$ \\
\hline
\end{tabular}

komunikasi dan kognisi. Konteks, kesan konteks dan usaha memproses maklumat diguna pakai bagi menjelaskan bagaimana makna kognitif di atas dapat dihasilkan. Jadi, tafsiran tentang mata sebagai isyarat berasaskan peranan konteks dan kesan kognitif. Konteks diambil daripada data korpus. Oleh sebab itu, analisis peringkat kedua ini mesti dikukuhkan lagi dengan data korpus. Data korpus adalah penting bagi membuktikan bahawa memang wujud hubungan antara objek dalam metafora ini dan kaitannya dengan premis tambahan bagi mengesahkan tentang makna yang diberikan. Perhatikan data korpus yang berikut: 
(i). Penguasaan pasukan sepak takraw sejak kejayaan pada Sukan Asia Beijing 1990 nampaknya tidak lama. Musuh tradisi, Thailand kembali menggugat. Hasilnya, Malaysia gagal mempertahankan pingat emas acara antara pasukan kepada negara Gajah Putih itu dan terpaksa berputih mata menyimpan hanya pingat emas acara antara regu. (ULS JANUARI 1994. Khas, 1994).

(ii). Dalam hubungan ini, individu tersebut akan berusaha sedaya upaya untuk mengaburi mata umum. Dia sanggup berbohong, berlakon dan memberi keterangan palsu semata-mata untuk membuat orang ramai percaya bahawa dia tidak terbabit langsung dengan kesalahan itu. (Wan Roslili Abd Majid. Taubat perlu dilakukan ikhlas, bersungguh-sungguh. Agama, 2003).

(iii). Tenanglah hati. Tenanglah! Sejurus aku dapat bernafas. Lega sedikit sesak di dada. Akan tetapi detik itu terlampau singkat bagiku. Beberapa ketika berikutnya, terasa semacam satu kengerian datang. Datang tanpa memberi salam lagi. Ia menghampiri dengan sebilah pisau tajam mengkilat. Bersinar mata pisau itu disambar cahaya. (Othman Putih. DUNIA BELUM BERAKHIR. Sastera, 1980).

(iv). Setelah mengikuti kursus ini minda kita akan membuka ruang lebih luas membolehkan kita melihat dengan mata hati dan fikiran yang matang bahawa masih banyak kelemahan dalam diri kita untuk menghadapi hari hadapan. (Rohana Ibrahim. Mahasiswa patut hadiri kursus. Surat Pembaca, 1994).

Daripada data korpus di atas, rangka rujuk silang (RRS) yang merupakan subkonsep dalam teori Relevans diaplikasikan. Tujuan RRS adalah untuk mendapatkan maklumat atau premis tambahan demi menyingkap makna apabila tidak wujudnya anteseden. Dalam contoh data korpus di atas, tiada maklumat harfiah atau anteseden yang merujuk makna metafora "mata" secara jelas. Hanya ada premis tambahan yang boleh membantu memperkukuh konteks ujaran. Konteks mampu mengaitkan metafora dengan premis tambahan yang ada dalam korpus di atas. Daripada keempat-empat contoh korpus di atas, klausa yang ditulis sendeng ialah premis tambahan sebagai maklumat konteks bagi memahamkan makna metafora yang digelapkan. Maklumat ini akan membuktikan bahawa secara kognitifnya, premis tambahan boleh meningkatkan kesan kognitif dan seterusnya merendahkan kos memproses maklumat dan sekali gus membantu mencapai pentafsiran makna yang dihajati. Premis tambahan akan menjelaskan lagi makna metafora tersebut. Meskipun teoi Relevans mampu mengungkapkan makna pada peringkat kognitif, namun teori ini gagal memberikan maksud sebenar yang hendak disampaikan pada 
tahap akal budi, terutama bagi menjawab persoalan mengapa objek itu dipilih dan kaitan dengan makna yang diberikan. Dengan itu, semantik inkuisitif ditawarkan pada tahap tiga bagi menjawab mengapa warna putih dipilih untuk menggambarkan kekecewaan, kabur mata bagi makna entiti yang tidak jelas. Mata pisau dan mata hati pula dipisahkan jenis ketajamannya.

Daripada analisis semantik inkuisitif, semua simpulan bahasa "mata" dikaitkan dengan keadaan mata secara fizikal. Warna "putih" yang terdapat dalam struktur mata seperti iris, pupil dan kanta menunjukkan simptom yang negatif (Muhamad, 2012). Hal ini selari dengan makna simpulan bahasa berputih mata yang menunjukkan makna negatif, iaitu kecewa atau menanggung malu. Mengapa "putih" pada selaput mata turut mempengaruhi "putih" dalam ungkapan berputih mata? Lazimnya putih merujuk sesuatu yang positif seperti yang dianjurkan dalam Islam. Namun begitu, dalam ungkapan ini warna putih dianggap sebagai sesuatu yang negatif berdasarkan maklumat kesihatan. Dalam kiasan Melayu, "berputih" sahaja tidak lengkap untuk menyampaikan makna yang tersirat. Objek "mata" telah digandingkan bersama dan membentuk makna yang negatif. Makna negatif ini telah dikonsepsikan sebagai isyarat perasaan kecewa dan menanggung malu.

Apakah akal budi yang terkandung di sebalik objek "mata" dalam ungkapan ini? Dalam budaya masyarakat Melayu, ketika berkomunikasi adalah penting bagi penutur dan pendengar memandang mata satu sama lain. "Mata" memainkan peranan yang sangat penting ketika berkomunikasi selain, gerak isyarat tubuh dan penampilan. Perbuatan memandang mata ketika berkomunikasi melambangkan adab sopan dan juga sebagai tanda pendengar fokus tentang apa-apa yang sedang diperkatakan. Oleh itu, sebarang kecacatan pada pancaindera mata akan mudah dikesan. Sekiranya terdapat sebarang kelainan pada pancaindera ini, pastinya akan menimbulkan perasaan malu pada si pengalami untuk bertentang mata dengan masyarakat.

Apakah falsafah di sebaliknya? Jika diperhatikan Rajah 4 yang dipetik daripada Muhaya (2012), terdapat persamaan antara dua bentuk, iaitu struktur mata yang berwarna putih disebabkan penyakit dengan perasaan kecewa dan malu. Hal ini jelas menunjukkan pemikir Melayu dahulu telah menganalogikan penyakit mata dengan simptom "putih" sebagai sesuatu yang negatif. Begitu juga dalam simpulan bahasa sehingga membentuk isyarat perasaan yang negatif, iaitu kecewa dan malu. Masyarakat Melayu telah meluaskan lagi konsep kecewa dan malu ini apabila gagal mempertahankan hak dan gagal dalam sesebuah perlawanan. Begitulah pekanya pengamatan pemikir Melayu dahulu yang berupaya mengaitkan objek mata berdasarkan konsep selaput putih pada mata kepada kecewa dan malu dalam ungkapan "berputih mata". Rajah 4 menunjukkan warna putih pada mata yang boleh disamakan dengan makna kecewa dalam metafora "putih mata". 

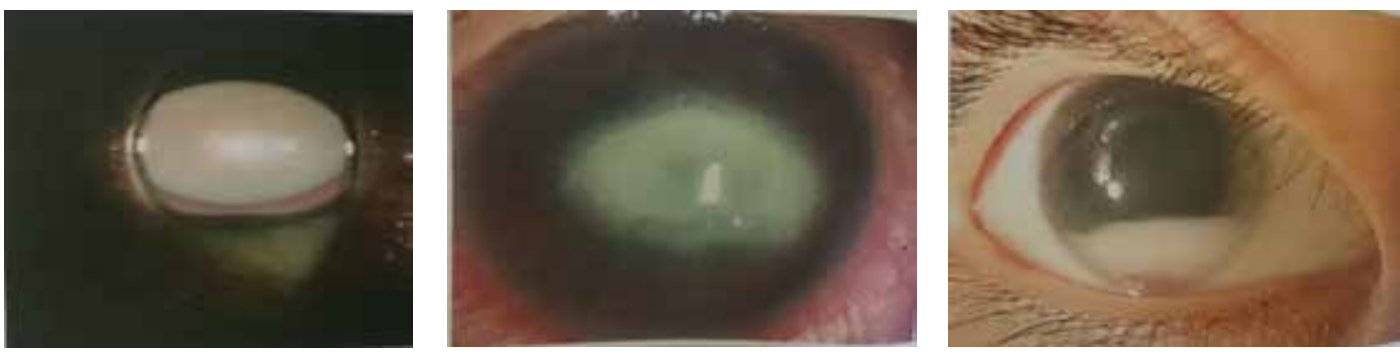

Rajah 4 Imej gambaran penyakit mata seperti Katarak, Ulser Kornea dan Retinoblastoma (Muhamad, 2012).

Begitu juga dengan ayat korpus (ii) di atas. Frasa berbohong, berlakon dan memberi keterangan palsu semata-mata untuk membuat orang ramai percaya merupakan premis tambahan kepada mengaburi mata. Frasa ini membekalkan konteks bagi pendengar memahaminya lantas mengukuhkan kesan kognitif pendengar. Dengan menggunakan RRS, frasa berbohong, berlakon dan memberi keterangan palsu semata-mata untuk membuat orang ramai percaya dapat dipautkan dengan "mengaburi mata". Maklumat yang terdapat dalam premis tambahan ini turut menggambarkan bahawa penipuan boleh dilakukan dengan kepura-puraan dan memutarbelitkan kebenaran.

Dalam kiasan Melayu, "kabur” sahaja tidak lengkap untuk menyampaikan makna yang tersirat. Objek "mata" telah digandingkan bersama dan membentuk makna yang negatif. Objek "mata" memainkan peranan sebagai penyuluh bagi memperlihatkan makna negatif. Makna negatif ini telah dikonsepsikan sebagai sesuatu yang tidak jelas dan pemikir Melayu dahulu telah memindahkan maknanya sebagai perbuatan penipuan dalam kiasan. Hal ini selari dengan pandangan mata yang tidak normal yang sukar melihat sesuatu objek dengan jelas. Dari sudut optometri, penglihatan yang tidak jelas seperti rabun boleh dirawat mengikut tahap kekaburan yang dialami seperti memakai cermin mata atau melakukan pembedahan. Hal ini berlainan dengan metafora mengaburi mata.

Dengan mata dan fikiran, manusia boleh membuat penilaian dan pengamatan terhadap sesuatu perkara sama ada dapat mendatangkan kebaikan atau kemudaratan. Dapatlah disimpulkan bahawa jika seseorang rabun, maka dia tidak boleh melihat dengan jelas atau ketidakupayaannya memfokus sehingga menyebabkan kabur penglihatan. Berdasarkan konsep ini, pemikir Melayu dahulu memadankan seseorang yang ditipu juga tidak dapat melihat atau menilai atau membuat pengamatan pada sesuatu perkara dengan jelas sehingga terpedaya. Bagi menutup sesuatu kesalahan, "kabur" dilakukan dengan mempengaruhi sama ada menggunakan wang, kuasa, janji manis, kemewahan dan sebagainya sehingga menghalang pandangan mata 
secara langsung. Begitu teliti dan tajamnya pemikiran masyarakat Melayu dahulu kerana berupaya menggunakan objek mata dan sifatnya dalam melambangkan perihal perlakuan manusia yang menjadikan entiti yang tidak jelas sebagai cara menipu (Noorfaiz, 2016). Begitulah seterusnya pemprosesan data (iii) dan (iv) di atas. Kali ini dikaitkan dengan ketajaman alat seperti pisau dan mata kail. Ditambah pula dengan ketajaman akal fikiran. Kesemua premis tambahan dapat membantu mengukuhkan pemahaman pembaca sehingga dapat difahami mengapa "mata pisau" dan "mata hati" dapat dikaitkan dengan mata dan ketajaman.

\section{(2) Simpulan Bahasa: Isi dengan Kuku}

Data kedua ialah simpulan bahasa "bagai isi dengan kuku" yang membawa maksud persahabatan yang erat. Makna harfiah ini hanya menyatakan perihal hubungan yang akrab. Namun begitu, ada falsafah yang lebih mendalam yang cuba disampaikan. Data korpus di bawah yang dicapai melalui prpm@dbp.gov.my dapat membantu penganalisisan elemen kognitif yang berada pada tahap kedua. Pada peringkat kognitif, data korpus ini berjaya mengupas lebih lanjut mengenai persahabatan ini, dan tidak tertakluk hanya kepada manusia tetapi harta, institusi dan konsep kejiranan.

(vi). Benar, wanita dan emas permata ibarat isi dan kuku, tidak boleh dipisahkan sama ada mengenakannya di majlis atau sekadar menjamu mata menikmati koleksi ...

(v) Ibarat isi dan kuku, begitu juga konsep Islam Hadhari dan Terengganu Bestari yang mempunyai keserasian dan kesinambungan ...

(vi). Molek berjiran akrab selalu erat bagai isi dengan kuku jika kurang kita berunjuk beri kalau berlebih tambah-menambah baik pekerti bak pohon rimbun naung bersayap kiri dan kanan ramai yang menumpang teduh dusun menjadi sama menjolok buah habis galah jangan dibuang

(Sumber:prpm@dbp.gov.my)

Sekali lagi tiga tahap analisis semantik diaplikasikan. Bermula dengan makna skrip, iaitu makna yang telah sedia diberikan seterusnya kepada makna kognitif. Makna skrip hanya membekalkan makna harfiah. Tiada maklumat lanjut tentang makna akal budi yang boleh dicapai pada tahap ini. Kemudian analisis skrip bergerak ke tahap resonans. Pada tahap ini dengan mengaplikasikan RRS kita dapat mengisi ruang mental bagi memahami maksud sebenar yang hendak disampaikan melalui 
simpulan bahasa ini. Konteks dan kesan kognitif yang terbina berasaskan premis tambahan ini membantu kita mendapatkan gambaran yang jelas mengenai simpulan bahasa ini. Berdasarkan ayat korpus di atas, contoh (iv) merujuk perihal eratnya hubungan antara wanita dan permata, contoh (v) Islam Hadhari dengan Terengganu Bestari dan contoh (vi) konsep berjiran. Semua ini dapat dikaitkan perihal konsep hubungan yang erat antara metafora dengan makna yang hendak disampaikan. Premis tambahan yang membantu memperkukuh kesan kognitif membantu pembaca memahami apa yang dikatakan hubungan yang erat itu. Hal ini sekali gus merendahkan kos memproses maklumat yang diperlukan bagi memahami konsep keakraban ini. Persoalannya mengapa kuku dan isi yang dipilih bagi menjelaskan mengenai hubungan?

Seperti yang telah dinyatakan di atas, analisis pada peringkat resonans perlu diteruskan ke peringkat inkuisitif. Dapat diperlihatkan bagaimana makna inkuisitif dihasilkan. Dalam kes metafora bagai isi dengan kuku, boleh dirujuk kepada tahap kesihatan seseorang [www.hellodoktor.com]. Asmah (1986), Hassan (2016) menyatakan masyarakat Melayu dahulu menjadikan anggota badan, alam dan lingkungannya sebagai iktibar lantas membentuk analogi seperti yang terkandung dalam metafora. Kuku dan isi memang sangat rapat. Di atas isi adanya kuku. Sebenarnya terdapat iktibar lain yang hendak disampaikan. Warna kuku dan struktur kuku boleh memberikan petanda awal tentang penyakit. Mengikut ruangan dalam blog Hello Doktor [www.hellodoktor.com], warna dan struktur kuku dapat dikaitkan dengan tahap kesihatan seseorang. Darah yang mengalir pada isi akan mempengaruhi warna dan struktur kuku. Dalam Rajah 5 telah dinyatakan bahawa kuku yang berwarna putih kemudian dilingkari oleh rim berwarna hitam menunjukkan bahawa seseorang itu mempunyai hepatitis dan jaundis. Mereka yang mempunyai kuku yang kekuning-kuningan menunjukkan seseorang itu mempunyai jangkitan kulat. Mereka yang mempunyai permukaan kuku yang tidak rata dan berlubang-lubang kecil menandakan psoriasis peringkat awal atau keradangan artritis. Kuku tidak mempunyai zat yang cukup daripada isinya pasti membawa isyarat tentang penyakit yang dialami.

Daripada situ maka dibuat satu analogi perihal eratnya hubungan kesihatan dengan kuku langsung dibuat simpulan bahasa yang lebih konkrit sifatnya. Hubungan yang erat berada pada domain A, namun untuk memudahkan pemahaman hubungan yang erat maka diambil "isi dan kuku" sebagai sesuatu yang konkrit bagi menjelaskan makna abstrak dalam domain A. Maka lebih mudah untuk kita memproses makna dalam ruang mental bagi mendapatkan pemahaman tentang konsep ini (rujuk Rajah 1 dan 2 di atas). Penerangan kesihatan dan hubungannya dengan "isi dengan kuku" di atas telah menjelaskan peranan inkuisitif, iaitu kenapa dan mengapa isi dan 
kuku dipilih sebagai objek dalam metafora ini. Metafora itu dikaitkan dengan tahap kesihatan. Betapa pentingnya dan eratnya isi dan warna kuku adalah sama eratnya hubungan sesuatu entiti. Akal budi terletak pad acara pemilihan objek metafora dan maknanya.

Kuku keputihan dilingkari warna hitam

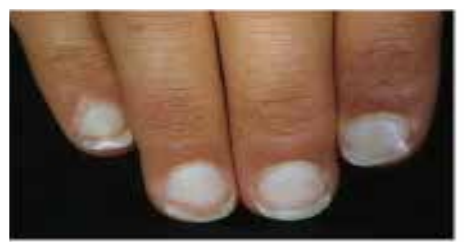

Hepititis dan jaundis
Kuku kekuningan-kuningan

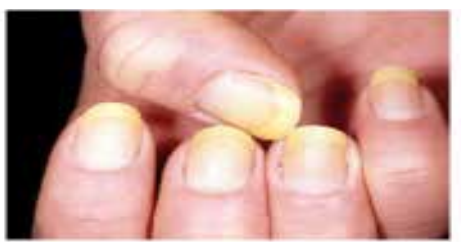

Jangkitan kulat
Kuku berlubang halus dan permukaan tidak rata

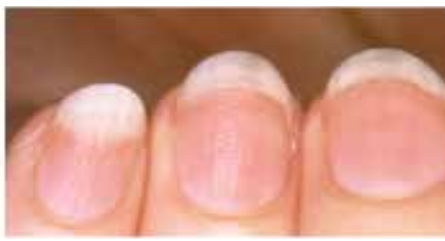

Peringkat awal psoriasis atau keradang arthritis

Rajah 5 Hubungan antara objek dan makna.

(Sumber: https://hellodoktor.com/ms/gaya-hidup-sihat/tips-kesihatan/kuku-dan-tahapkesihatan/)

\section{ULAM DAN PANTUN}

Selain simpulan bahasa dan peribahasa, pantun juga merupakan salah satu metafora yang boleh disoroti dan diteliti makna dan falsafahnya. Salah satu aspek yang menarik untuk dikaji ialah hubungan antara ulam, pantun dan kaitannya dengan akal budi Melayu. Julaina et al. (2018) dan Santich (2004) menghuraikan bahawa pemakanan ada nilai yang boleh dicerapi dan membawa maksud lebih sekadar mengenyangkan perut. Analisis ulam-ulaman ini boleh membuktikannya. Sekali lagi semantik inkuisitif cuba ingin menjawab mengapa sesuatu objek itu dipilih dalam pembentukan pantun-pantun ini. Objek dalam pantun ini mempunyai nilai abstrak yang tinggi yang menuntut pemikiran aras tinggi untuk kita menanggapi maksud tersirat yang cuba disampaikan. Sekali lagi semantik inkuisitif yang mengambil kira data, kognitif, teori, falsafah dan budaya, untuk cuba mencungkil akal budi di sebalik penghasilan metafora Melayu. Pantun yang bersifat tersirat dengan pembayang dan maksud boleh dimasukkan dalam kategori ini. Empat ulam-ulaman dipilih berdasarkan pantun yang diberikan di bawah. Keempat-empat ulam tersebut ialah selasih, petai, timun dan pegaga. Proses yang sama, iaitu daripada skrip kepada inkuisitif akan melatari analisis ini. Namun begitu, bagi mengelakkan proses analisis pada tahap harfiah dan kognitif berulang, maka analisis inkuisitif sahaja yang akan 
diberikan. Yang dipentingkan dan yang hendak dicungkil ialah akal budi di sebalik pantun ulam-ulaman ini.

\section{Selasih}

Daun selasih juga dipanggil kemangi di Perak. Perhatikan pantun di bawah. Kesemua pembayang selasih dapat dikaitkan dengan kasih sayang. Ungkapan maksud pantun yang ketara seperti "tempat berkasih", "kasih bukan kepalang", "setinggi penghargaan", "disanjung mulia", "kasih saya turutkan", dapat dikaitkan perihal kasih sayang. Dalam pendekatan semantik inkuisitif, mengapa setiap objek dan makna dipilih ada falsafahnya. Ungkapan kasih yang diberikan adalah sesuatu yang abstrak yang sukar diukur. Lantas objek yang abstrak ini mesti dikonkritkan bagi memudahkan kita memahami konsep kasih sayang dalam konteks masyarakat Melayu. Maka dilakukan pemetaan minda antara hal yang abstrak ini kepada ulam selasih yang ternyata wangi, harum dan enak rasanya. Ulam ini boleh mewangikan tubuh badan dan menyegarkan bau mulut. Penggunaannya melahirkan perasaan nyaman dan selesa senyaman kasih dan sayang. Selasih yang dicampurkan dalam masakan sayur air/manis dan gulai lemak labu contohnya, memang dapat menghasilkan aroma dan mampu membangkitkan selera. Maka sesuailah kasih sayang ini dipetakan dengan ulam selasih. Contoh pantun berobjekkan selasih adalah seperti di bawah:

Jintan pulau rempah bertempat

Cari di para biji selasih

Jika merantau mencari tempat

Cari saudara tempat berkasih

Rendam selasih gula secawan

Selasih ada tepi telaga

Terima kasih setinggi penghargaan

Budi dan jasa disanjung mulia.

Nasi lemak buah bidara

Sayang selasih saya lurutkan

Buang emak buang sedara

Sebab kasih saya turutkan

(www.malaycivilization.com) 
Rata-rata orang Melayu dahulu mengenali selasih. Maka dari segi konteks dan kesan kognitifnya amat mudah untuk difahami oleh pendengar pada tahap kognitif. Pengalaman memakan ulam ini memudahkan pendengar memproses maksud kasih sayang yang hendak disampaikan dengan keharuman selasih itu sendiri.

\section{Petai}

Dalam soal selidik yang dilakukan (Jalaluddin, 2019), petai ialah ulam yang dimakan oleh kebanyakan warga Malaysia. Malah petai menduduki lebih daripada 50\% pemakanan

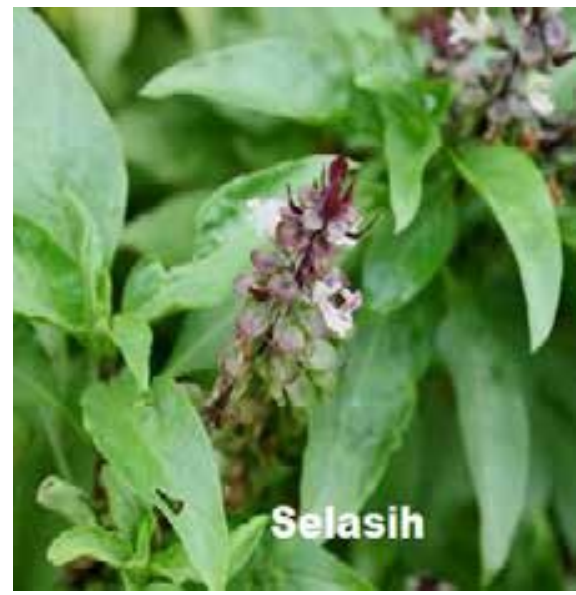

Rajah 6 Daun dan bunga selasih. (Sumber: Google Image) di tiap negeri. Pantun berobjekkan petai berkaitan dengan orang berilmu. Petai meninggalkan bau kepada si pemakan. Namun begitu, baunya tidak sekuat jering. Pemakan petai mengatakan petai itu lemak, kelat dan sedikit pahit. Petai meninggalkan bau dan boleh dikesan jika seseorang memakannya. Rajah 7 di bawah dikeluarkan oleh Kementerian Kesihatan Malaysia. Perhatikan banyak khasiat petai kepada pemakan. Maka ulam ini boleh membantu menyihatkan badan. Khasiat seperti vitamin A, C, kalium dan kalsium mampu menguatkan tulang dan gigi, mengawal kesihatan jantung dan keseimbangan air badan. Petai juga bermanfaat untuk meningkatkan imun badan dan bersifat antioksida.

Ternyata apa-apa yang dinyatakan di atas tentang kelebihan petai mempunyai persamaan dengan yang dikeluarkan oleh Kementerian Kesihatan Malaysia. Badan yang

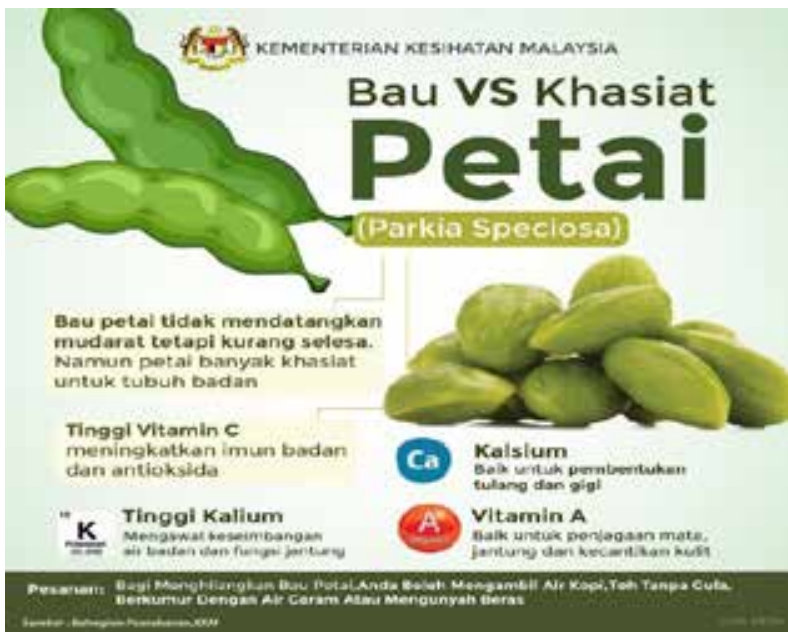

Rajah 7 Petai dan khasiatnya.

(Sumber http://www.doa.gov.my) 
sihat pastinya melahirkan minda yang cerdas. Dari segi pragmatiknya bau yang ada pada petai boleh ditafsirkan sebagai ilmu yang boleh dikesan pada individu. Pantun di bawah jelas menggambarkan perihal ilmu dengan pembayang petai. "Dilarang menjadi perantara jika tidak berilmu", "orang berilmu sentiasa diundang dan dijamu", "orang berilmu berfikiran terbuka" dan sentiasa mengikuti perkembangan zaman. Ciri-ciri ini bersesuaian dengan ciri-ciri orang berilmu.

Lalu berempat orang Kubong

Ka baroh membawa petai

Jika ta' tahu kata berhubong

Tiada sah menjadi pegawai

Sungguh beruntung membeli petai

Baunya wangi di mulut orang

Sungguh beruntung menjadi lebai

Ke mana pergi perutnya kenyang

Kurang garam tambah cuka

Hendak menjeruk sepapan petai

Hati ikhlas fikiran terbuka

Bagai pasir menghampar pantai

Asam kandis buah petai

Dibawa orang dari Sabah

Ibarat pasir di tepi pantai

Sekali air bah sekali berubah

(Sumber: www.malaycivilization.com)

Daripada pantun di atas jelas menunjukkan bergunanya petai sehingga dibawa sebagai buah tangan semasa berkunjung ke sesuatu tempat. Selain dimakan mentah, petai dijeruk sebagai penambah selera pemakan. Malah pengalaman kita memakan atau dekat dengan orang yang memakan petai akur dengan bau petai ini. Perihal berkunjung, menjeruk makanan ialah amalan biasa masyarakat Melayu. Meskipun mempunyai bau, petai tetap dimakan. Ini semua adalah selari dengan persekitaran kognitif masyarakat Melayu. Tidak sukar memahami ciri petai ini. Kemudian pembayang pantun ini dikaitkan pula dengan maksud pantun. Objek petai dalam pantun di atas dikaitkan dengan orang perantara, orang berilmu orang 
yang berfikiran terbuka. Dari segi falsafah dan budaya, orang berilmu orang yang dihormati dalam masyarakat. Orang yang boleh diajak berbincang. Hal orang berilmu ini merupakan pemahaman yang abstrak. Maka pemetaan abstrak kepada objek konkrit mesti dilakukan bagi memahami perilaku petai. Orang berilmu ada tanda seperti kemampuannya menyusun idea atau berhujah berdasarkan fakta sama seperti bau yang boleh dihidu. Memandangkan petai meninggalkan bau, sifat ini boleh disamakan dengan ciri orang berilmu. Dari tutur kata dan tingkah laku, orang berilmu pasti dapat dikesan seperti mudahnya kita mengenali kesan si pemakan petai. Di samping bau, khasiat petai yang banyak mengesahkan lagi kebaikan petai ini.

\section{Timun}

Kita lihat pula data timun. Dalam kajian Nor Hashimah Jalaluddin (2019) tentang ulam-ulaman Melayu, $\quad 98 \%$ responden mengatakan mereka memakan timun sebagai ulam. Timun merupakan peratus tertinggi daripada semua jenis ulam yang dimakan. Timun bukan sahaja dimakan mentah tetapi juga dibuat acar. Timun menjadi ulam terpenting dalam laksa asam, nasi ayam, laksam, laksa Johor. Timun juga menjadi sumber yang paling cepat dan ringkas jika

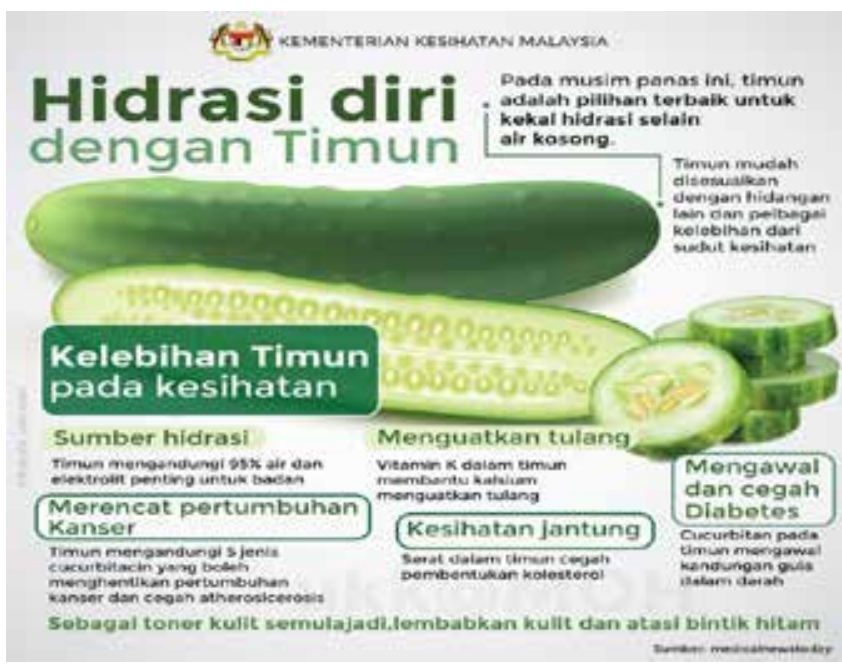

Rajah 8 Khasiat timun.

(Sumber: http://www.doa.gov.my) tiada sayur lain yang dihidang sebagai pengimbang sajian terutama di Johor. Mengikut poster yang dikeluarkan oleh Kementerian Kesihatan seperti di bawah, banyak khasiat timun ditemui. Antaranya sebagai sumber menghidrasi diri terutama pada musim panas, merencatkan pertumbuhan kanser, menguatkan tulang, menjaga kesihatan jantung dan mencegah diabetes. Timun mengandungi $95 \%$ air yang baik untuk tubuh seseorang.

Bagaimana timun dapat dikaitkan dengan akal budi Melayu? Pantun dan peribahasa yang berikut dapat memberikan gambaran sifat timun. 
i. Bagai timun dengan durian: orang yang lemah ditindas oleh orang yang berkuasa

ii. Bagai timun dendang, di luar merah di dalam pahit: mulut manis hati busuk.

Contoh pantun "timun"

Buat pagar tanamkan timun

Timun ditanam di tepi paya

Apa lah gobar ribut turun

Pedoman ada di tangan saya

Timun sebutir bawa bertatang

Ulam laksa orang Jawa

Pahit getir terpaksa ditentang

Walau terpaksa menggadai nyawa

Cecahnya nanas sama mentimun

Timun sebutir bawa bertatang

Walau berpanas atau berembun

Pahit getir terpaksa ditentang

Kalau tuan pergi ke Ledang

lngatlah hendak mendaki bukit

Tuan laksana timun dendang

Di luar merah di dalam pahit

(Sumber: www.malaycivilization.com)

Daripada peribahasa dan pantun di atas, kita dapati bahawa ada dua fakta yang boleh dikaitkan dengan timun. Pertama sifatnya yang lemah sesuai dengan kandungan air di dalamnya, pokok yang mesti bersokong agar tidak rebah. Lantaran kelemahan itu, timun menjadi mangsa buli durian seperti dalam metafora "bagai durian dengan mentimun" (Hassan, 2016). Maksudnya timun berada pada pihak lemah dan menjadi mangsa orang yang berkuasa. Ada juga sifat timun dendang yang berwarna merah tetapi pahit rasanya, iaitu mulut manis tetapi ada sifat khianat. Di sisi lain pula, sifat timun yang kental. Ungkapan seperti "pedoman ada di tangan saya", "walau terpaksa menggadai nyawa", "pahit getir terpaksa ditentang", merupakan pendirian yang kuat. Meskipun fitur buah itu lemah tetapi khasiat yang ada pada buah itu sangat bermanfaat. Seperti khasiatnya boleh menjadi benteng kesihatan begitu jugalah makna yang cuba disampaikan dalam pantun di atas. Meskipun lemah, timun 
mempunyai ciri yang tinggi peribadinya. Dan pada masa yang sama boleh bertindak balas seperti digambarkan dengan timun dendang yang pahit dan ada kaitan dengan hati yang busuk. Pantun di bawah dapat mengesahkan lagi sifat timun:

Semak samun hutan-nya paku

Tidak seperti kebun manggis

Buah timun demikian laku

Dah masak masam muda manis

\section{Pegaga}

Seperti timun dan petai, skor responden yang memakan pegaga juga melebihi 90\%, tercatat dalam kajian ulam-ulaman yang dilakukan oleh Nor Hashimah Jalaluddin (2019). Pegaga ialah ulam yang mudah ditanam, kecil dan melata. Di Johor, pegaga menjadi makanan yang dihidang kepada mereka yang dalam pantang. Pegaga diurap dan selalunya dimakan bersama ikan goreng atau ikan bakar. Pegaga selalu juga dijadikan ulaman mentah dan dimakan

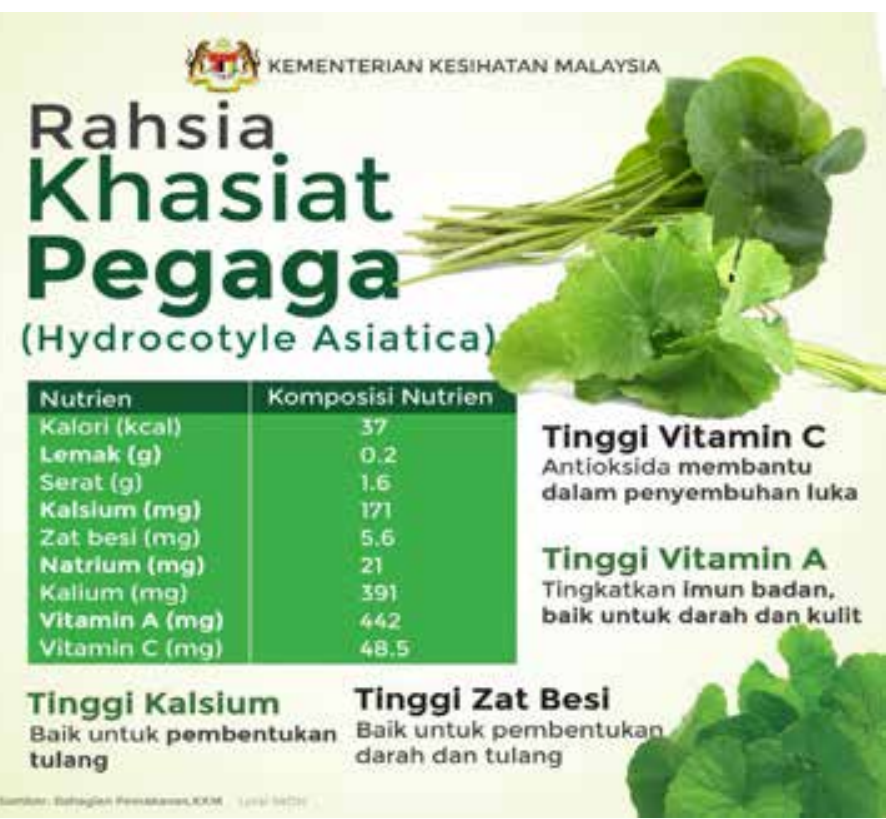

Rajah 9 Khasiat pegaga.

(Sumber: http://www.doa.gov.my) dengan sambal belacan.

Hampir semua negeri di Malaysia memakan pegaga mentah dengan sambal belacan. Dari segi khasiatnya, memang tidak dinafikan. Malah UNESCO telah mengiktiraf makan pegaga dengan kecerdasan minda. Ada juga yang mengamalkan minum air pegaga bersama rebusan halia, serai dan ditambah madu untuk rasa yang sedap dan pada masa yang sama memberikan kesan yang baik untuk kesihatan. Malah telah ada jus pegaga yang dijual di restoran. Teh perisa pegaga turut dijual. Menurut Kementerian Kesihatan Malaysia, terdapat vitamin A, C, kalsium dan zat besi pada 
pegaga. Khasiat pegaga mampu menyembuhkan luka, meningkatkan imun badan, baik untuk pembentukan darah dan tulang. Ulam yang berserat juga baik untuk penghadaman. Rajah 9 dapat menjelaskan lagi khasiat pegaga.

Pegaga juga boleh dikaitkan dengan akal budi Melayu. Di bawah dipaparkan pantun yang boleh dikaitkan dengan imej pegaga, iaitu kasih sayang.

Di dalam raga kerang dan kepah

Ulam pegaga dibuat laksa

Kepada keluarga kasih tertumpah

Moga bahagia sepanjang masa

Ikan karuk si ikan haruan

Dicampur pegaga makanan Cik Nyonya

Seburuk-buruk kain basahan

Tertutup juga malu olehnya

Daun pegaga daun kasturi,

Dipetik dara untuk ibunda;

Tidak terhingga ilmu diberi, Hargailah guru selagi ada.

Ulam pegaga merumpun di huma

Tepi pinggiran hujungan kuala

Dalam keluarga rukun bersama

Hadapi cabaran dengan rela

(Sumber: www.malaycivilization.com)

Perhatikan ungkapan seperti "Kepada keluarga kasih tertumpah", "Seburuk-buruk kain basahan, Tertutup juga malu olehnya", "hargailah guru selagi ada", "dalam keluarga rukun bersama Hadapi cabaran dengan rela". Kesemua ungkapan ini ada hubung kait dengan pertalian darah, maruah dan menghormati satu sama lain. Ibarat dengan memakan pegaga dapat menguatkan tulang dan darah begitu jugalah bayangan yang diberikan dalam pantun ini. Falsafah di sebalik pantun yang abstrak ini dapat dipetakan pada khasiat pegaga. Khasiat ulam yang baik boleh dipetakan dengan elemen kasih sayang yang cuba dibawa dalam pantun ini. Sungguhpun tumbuh melata, pegaga tidak dianggap melarat. Kebaikannya dicari dan dimakan sebagai makanan kesihatan. Malah kepelbagaian hasil pegaga membuktikan yang pegaga amat baik untuk diamalkan sebagai ulam. 


\section{KESIMPULAN}

Berdasarkan dua simpulan bahasa dan empat ulam di atas, kita dapati ada hubung kaitnya antara objek dalam metafora dengan makna yang hendak disampaikan. Di sinilah terletaknya akal budi Melayu, kebijaksanaan masyarakat dahulu yang memetakan mata, kuku dan khasiat ulam-ulaman dengan peribahasa dan pantun Melayu. Dalam ilmu semantik, kita mesti dapat mengaitkan makna abstrak dalam metafora dengan makna konkrit bagi memastikan kita memahami falsafah yang terkandung dalam metafora itu sendiri. Pengalaman dan persekitaran kognitif pendengar dapat diperkaya dengan melihat kepada konteks metafora itu diujarkan, leksikal yang dipilih dan makna yang diberikan memang menampakkan hubungan kognitif antara objek dan makna. Inilah yang dikatakan akal budi Melayu. Semua peribahasa, pantun ada falsafah tersendiri dan ilmu semantik inkuisitif mampu merungkaikannya. Sesungguhnya kajian yang melibatkan akal budi boleh memberikan perspektif baharu kepada kajian metafora Melayu. Kebijaksanaan memilih objek dalam metafora memberikan isyarat bahawa apa-apa yang dicipta mempunyai hubungan rapat dengan makna, alam dan persekitaran penuturnya sendiri.

\section{RUJUKAN}

Abdullah, Hussain. (2003). Kamus Simpulan Bahasa. Kuala Lumpur: Dewan Bahasa dan Pustaka. Abdul Samad Idris. (1989). Dengan 300 Pepatah. Kuala Lumpur: Pustaka Budiman.

Asmah Haji Omar. (1986). Bahasa dan Alam Pemikiran Melayu. Kuala Lumpur: Dewan Bahasa dan Pustaka.

Azhar M. Simin. (1993). Sintaksis Wacana 'Yang' dalam Bahasa Melayu. Kuala Lumpur: Dewan Bahasa dan Pustaka.

Black, J. Charteris. (2000). Figuration, Lexis and Cultural Resonance: A Corpus Based Study of Malay. Pragmatics, 10(3), 281-300.

Black, J. Charteris. (2002). Speaking With Forked Tongue: A Comparative Study of Metaphor and Metonymy in English and Malay Phraseology. Metaphor and Symbol, 18(4), 289-308.

Goddard, C. (1999). Like Crab Teaching its Young to Walk: Proverbiality, Semantics and Indexicality in English and Malay. Akses daripada http://www.researchgate.net/publication/ Hassan Ahmad. (2003). Metafora Melayu: Bagaimana Pemikir Melayu Mencipta Makna dan Membentuk Epistemologinya. Sungai Ramal Dalam: Akademik Kajian Ketamadunan. Hassan Ahmad. (2016). Bahasa dan Pemikiran Melayu. Kuala Lumpur: Dewan Bahasa dan Pustaka.

https://hellodoktor.com/ms/gaya-hidup-sihat/tips-kesihatan/kuku-dan-tahap-kesihatan/

Imran Ho Abdullah. (2011). Analisis kognitif semantik peribahasa Melayu bersumberkan anjing (canis familiaris). Gema Online ${ }^{\mathrm{TM} J o u r n a l ~ o f ~ L a n g u a g e ~ S t u d i e s, ~ 11(1), ~ 125-141 . ~}$ 
Julaina Nopiah, Nor Hashimah Jalaluddin, \& Junaini Kasdan. (2018). Refleksi Gastronomi dalam Komunikasi: Analisis Semantik Inkuisitif. Jurnal Komunikasi, 34(1), 185-201.

Koleksi Pantun Melayu. Akses daripada [www.malaycivilization.com dicapai 20 September 2019]

Lakoff. G, John M. (1980). Metaphors We Live By. Chicago: The University of Chicago Press.

Laman sesawang rasmi Kementerian Pertanian Malaysia[http://www.doa.gov.my - dicapai 10 Oktober 2019]

Maxwell, W.E. (1878). Malay Proverbs. JSBRAS, 1(7), 85 -98.

Mogan, Jamuna Rani. (2014). Peribahasa Haiwan dalam Bahasa Tamil: Analisis Semantik Kognitif (Kertas Projek Sarjana Tidak Diterbitkan). Program Linguistik, UKM.

Muhamad, Muhaya. (2012). Peliharalah Matamu ke arah yang Sihat. Selangor: As-Sohwah Enterprise.

Noorfaiz Pakharadzi. (2016). Simpulan Bahasa "MATA": Analisis Semantik Inkuisitif (Kertas Projek Program Linguistik Tidak Diterbitkan). Bangi: UKM.

Nor Hashimah, Jalaluddin. (2014). Semantik dan Akal Budi Melayu. Bangi: Penerbit Universiti Kebangsaan Malaysia.

Nor Hashimah Jalaluddin. (2017). Semantik dan Interpretasi. Kuala Lumpur: Dewan Bahasa dan Pustaka.

Nor Hashimah Jalaluddin. (2018). Peribahasa dan Akal Budi Melayu. Nor Hashimah dan Maslida (Eds.), Kiasan, Kognitif dan Akal Budi Melayu. Bangi: Penerbit UKM

Nor Hashimah Jalaluddin. (2019). Ulam-ulaman dan Akal Budi Melayu. Prosiding Seminar SEGEMUK, 26 Oktober. Bangi: Hotel Tenera.

Rogayah Othman. (2011). Peluasan Makna Pancaindera Hidung, Mata dan Mulut dalam Melayu: Kajian Semantik Kognitif (Tesis Phd. tidak diterbitkan). Program Linguistik, Universiti Kebangsaan Malaysia.

Santich, B. (2004). The Study of Gastronomy and its Relevance to Hospitality Education and Training. International Journal of Hospitality Management, 23(1), 15-24. Akses daripada http://www.sciencedirect.com/science/article/pii/S0278431903000690.

Sperber D, Wilson D. (1995). Relevans Theory: Communication and Cognition. Oxford: Basil Blakewell.

Winstedt, R.O. (1950). Malay Proverbs. London: J Murray.

Winstedt, R.O. \& Wilkinson, R.J. (1957). Pantun Melayu. Singapura: Malay Publishing House.

www.hellodoktor.com

www.malaycivilization.com

www.prpm@dbp.gov.my

Zaitul Azma Zainon Hamzah \& Ahmad Fuad (2011). Peribahasa Melayu Penelitian Makna dan Nilai. Serdang: Penerbit UKM.

Tarikh Peroleh (received): 17 Oktober 2019

Tarikh Terima (accepted): 29 April 2020 